\title{
Integrasi Modul Energi Surya untuk Membantu Sistem Kelistrikan di Pondok Pesantren Darul Bayan Kecamatan Jatinangor Kabupaten Bandung
}

\author{
Integration of Solar Energy Module to Help the Electricity System in Darul Bayan Islamic \\ Boarding School, Jatinangor District, Bandung Regency
}

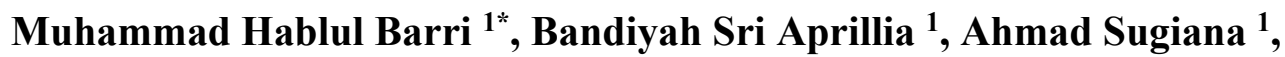 \\ Kharisma Bani Adam ${ }^{1}$ \\ ${ }^{1}$ Fakultas Teknik Elektro, Universitas Telkom, Bandung, Jawa Barat \\ *mhbarri@telkomuniversity.ac.id
}

\begin{abstract}
ABSTRAK
Pesantren Darul Bayan di bawah naungan pembinaan Yayasan Darul Bayan Pembangun Peradaban terletak daerah di Desa Cilayung Kecamatan Jatinangor Kabupaten Sumedang Jawa-Barat. Luas tanah yang dimiliki pesantren Darul Bayan sekitar 3000 (tiga ribu) meterpersegi, Di samping kegiatan kepesantrenan, Yayasan Darul Bayan Pembangun Peradaban membuat sekolah non formal (madrasah alquran) yaitu mulai dari tingkat SD sampai SMA, Jumlah santri kurang lebih ada 250 orang putra-putri, dua keluarga yang menetap, dan 20 orang guru. Pemenuhan energi listrik untuk kebutuhan sehari-hari di pesantren ini bersumber dari PLN dengan total daya sebesar 4400 VA. Biaya bulanan untuk penggunaan listrik rata-rata mencapai Rp 1.500.000 (satu setengah juta rupiah) tiap bulan. Biaya sebesar itu tentu sangat memberatkan, sebab tidak semua santri berkecukupan untuk membayar sumbangan pembinaan pendidikan (SPP) sebagai sumber biaya operasional bulanan. Oleh karena itu perlu ada upaya untuk meringankan biaya yang ditanggung pesantren. Masalah lain adalah keandalan listrik atau gangguan terputusnya saluran dan drop tegangan, serta sistem penerangan gerbang depan serta penerangan bilik di pesantren belum memadai. Untuk membantu meringankan biaya bulanan dan meningkatkan keandalan kelistrikan, maka dipasang Pembangkit Lisrik Tenaga Surya (PLTS). Sistem tersebut meliputi panel sel surya (gabungan beberapa modul sel surya), baterai, inverter, monitoring-kontroler, saklar, stop kontak, sensor photocell, dan pelengkap lainnya. Panel sel surya akan mengalirkan energi menuju baterai pada siang hari, pada malam hari lampu dapat dinyalakan secara otomatis maupun manual. Power House atau Pusat Daya PLTS akan dipasang di bangunan utama pondok pesantren, sehingga pemantauan PLTS akan lebih mudah.
\end{abstract}

Kata kunci — PLTS, pesantren, energi terbarukan

\begin{abstract}
Darul Bayan Islamic Boarding School under the auspices of the Darul Bayan Pembangan Bangsa Foundation is located in Cilayung Village, Jatinangor District, Sumedang Regency, West Java. The land area owned by the Darul Bayan Islamic boarding school is around 3000 square meters. In addition to the formal activities, the Darul Bayan Pembangun Bangsa Foundation has created non-formal schools (madrasah al-quran), starting from elementary to high school levels, the number of students is approximately 250 students, two living families, and 20 teachers. The fulfilment of electrical energy for daily needs at this boarding comes from PLN with a total power of $4400 \mathrm{VA}$. The monthly fee for electricity usage reaches an average of IDR 1,500,000 (one and a half million rupiah) per month. Such a large fee is of course very burdensome, because not all students are sufficient to pay educational development contributions as a source of monthly operational costs. Therefore, efforts are needed to reduce the costs borne by the school. Another problem is the reliability of electricity or disruption of line cut outs and voltage drops, as well as inadequate lighting for the front gate and room lighting in the boarding school. To help reduce monthly costs and improve electrical reliability, a Solar Power Plant (PLTS) is installed. The system includes a solar cell panel (a combination of several solar cell modules), a battery, an inverter, a monitoring-controller, a switch, a socket, a photocell sensor, and other attachments. The solar cell panels will flow energy to the battery during the day, at night the lights can be turned on automatically or manually. The Power House or PLTS Power Centre will be installed in the main boarding school building, so that monitoring of the PLTS will be easier.
\end{abstract}

Keywords - Cadres, Early Detection, High Risk Pregnancy 


\section{Pendahuluan}

Pada era globalisasi saat ini, pesantren dituntut untuk mandiri dalam segala hal, khususnya dalam segi ekonomi. Jika sumber pemasukan pesantren hanya berasal dari sumbangan dan biaya bulanan santri, maka akan sulit warga pesantren untuk berdikari dan cenderung akan mudah terpengaruh oleh kondisi eksternal (Solichin, 2012 [4] ). Banyak pesantren besar yang sudah mulai memutar roda perekonomiannya dengan membuat unit-unit usaha seperti pertanian, peternakan atau usaha air kemasan (Hafidh and Badrudin, 2019; Solichin, 2012 [2]). Dilain sisi, pesantren yang belum memiliki unit usaha sendiri terpaksa harus berpikir keras bagaimana menghemat biaya pengeluaran setiap bulannya, mulai dari konsumsi santri dan para ustadz hingga keperluan lain seperti air, listrik dan sebagainya.

Pesantren Darul Bayan terletak di Desa Cilayung, kecamatan Jatinangor, Kabupaten Bandung Jawa Barat, Pesantren Darul Bayan ini digagas oleh $\mathrm{KH}$ Ali Bayanullah, Al-Hafidz. Berdasarkan hasil survei tim pengabdian masyarakat (PKM) Sumber Listrik dari PLN dengan daya sebesar $4400 \mathrm{VA}$, KWh meter dipasang di dinding bangunan utama pondok dan di dinding ruang kantor kepala sekolah terpasang juga sumber listrik dengan daya 4400 VA. Saat ini Pondok Pesantren Darul Bayan memiliki beberapa ruang dan gedung, yaitu masjid bergabung dengan ruang kelompok bermain (KOBER) anak - anak dari masyarakat sekitar, beberapa buah kelas untuk SMP, yang siswanya tidak hanya dari masyarakat setempat tapi dari luar daerah, sehingga memerlukan asrama baik untuk putra maupun putri.

Ada dua KWh meter PLN yang di pasang di pesantren, yaitu di bangunan utama pondok dan di kantor kepala sekolah dengan kapasitas arus mcb masing-masing 10 Ampere, 220 Volt, sehingga total daya maksimum yang dapat dipakai sebesar 4400 VA. Walaupun demikian keandalan PLN ini masih kurang, sering kali terjadi pemutusan dan drop tegangan karena lokasi pesantren jauh dari gardu PLN Permasalahan yang dihadapi di Pesantren Darul Bayan adalah:

a. Biaya listrik bulanan yang sangat besar b. Sering terjadi pemutusan dan drop tegangan karena lokasi pesantren jauh dari gardu PLN.

c. Pemutusan yang terjadi mengakibatkan gangguan untuk beban emergensi, bebanbeban yang penting dan mendesak, misalnya computer server.

d. Ketergantungan pada listrik PLN sangat besar sehingga hal ini dapat mengakibatkan bertambahnya pemanasan global

Dari permasalahan-permasalahan tersebut, maka akan lebih baik jika terdapat alternatif pasokan listrik selain dari PLN. Melihat kondisi geografis dan ketersediaan sumber daya, pesantren Darul Bayan lebih sesuai jika dibangun suatu pembangkit listrik tenaga matahari/surya. Panel surya serupa juga pernah diaplikasikan di beberapa pesantren (Abrori et al., 2017 [1] ; Nurmahaludin and Cahyono, 2020 [3] ). Dari pemasangan yang telah dilakukan didapati manfaat yang besar khususnya dalam hal biaya listrik yang dikeluarkan setiap bulan. Upaya dalam meningkatkan kemandirian listrik bagi masyarakat ini diharapkan juga dapat memicu pertumbuhan ekonomi di pesantren terutama dalam menekan pengeluaran pada listrik PLN.

\section{Target dan Luaran}

Berikut ini merupakan solusi pengabdian masyarakat yang ditawarkan untuk menyelesaikan permasalahan yang diangkat:

a. Menyediakan energi alternatif selain PLN yaitu dengan memanfaatkan PLTS

b. Memfasilitasi instalasi sistem PLTS beserta pengadaan komponen-komponen yang diperlukan

c. Melakukan instalasi penerangan pada gerbang dan bilik pondok dengan memanfaatkan energi dari PLTS yang sudah terpasang

d. Memberikan penyuluhan singkat tentang penggunaan dan perawatan PLTS pasca instalasi.

Untuk luaran dari kegiatan ini berupa produk jadi berupa "Integrasi Modul Energi Surya" beserta modul pedoman singkat pemeliharaan PLTS. Sistem Penyimpan energi melalui kontroler dan baterai beserta monitoring melalui GSM modul. 
Sistem Energi Surya yang akan diintegrasikan meliputi: (gabungan beberapa modul sel surya), baterai, inverter, monitoring, saklar, stop kontak, sensor photocell, dan pelengkap lainnya Sedangkan, Materi penyuluhan yang akan disampaikan ke masyarakat sasar, mengenai Penggunaan Energi Listrik Tenaga Surya di Pesantren Darul Bayan, Jatinangor, Kab. Bandung. Modul Penyuluhan yang sederhana terdiri :

a. Definisi, cara kerja dan spesifikasi sel surya.

b. Cara kerja sistem penyimpanan energi surya melalui baterai.

c. Cara penyambungan dari sel surya, baterai dan beban lampu penerangan.

d. Cara perawatan dan pemeliharaan modul sel surya dan baterai.

\section{Metodologi}

Metode pelaksanaan dari kegiatan ini secara garis besar dapat dikelompokkan sebagai berikut:

a. Survei lapangan yang lebih detail untuk mengetahui keberadaan situasi dan kondisi geografis di pesantren Darul Bayan, untuk itu dilakukan analisis strength, weakness, opportunity and treaten (SWOT).

b. Konsolidasi tim pelaksana abdimas. Selain dosen, tim juga dibantu tenaga administrasi, teknisi dari Telkom University, dan beberapa mahasiswa. Untuk mahasiswa kegiatan abdimas ini akan menjadi bagian dari tugas akhir (TA).

c. Pembelian peralatan dan bahan-bahan yang berkenaan dengan sistem PLTS. Setelah kondisi lokasi sudah tergambarkan, maka desain dari sistem dan daftar komponen dapat disesuaikan dengan kondisi di lapangan dan mulai dilakukan pengadaan barang.

d. Melakukan dan memberikan penyuluhan tentang pemasangan dan perawatan PLTS. Sebelum dilakukan instalasi, masyarakat sasar terlebih dahulu dikenalkan mengenai teknologi yang ingin diimplementasikan, mulai dari cara kerja, pengertian hingga segala yang berkaitan dengan perawatan dan perbaikan sistem.

e. Melakukan pengujian dan pengukuran terhadap sistem PLTS yang sudah terpasang. Pengujian meliputi pengukuran tegangan inverter, baterai dan output dari panel surya. Pengujian juga dilakukan pada instalasi listrik untuk penerangan gapura dan teras.

f. Evaluasi kegiatan. Kegiatan ditutup dengan evaluasi yang diisi dengan pembagian kuesioner mengenai kepuasan mengikuti kegiatan yang diselenggarakan dan harapan ke depan kegiatan seperti apa yang ingin dilakukan jika diberi kesempatan melakukan kegiatan PKM pada lingkungan pesantren.

\section{Pembahasan}

Partisipasi masyarakat sasar yang mengikuti kegiatan ini berjumlah kurang lebih 10 orang yang terdiri santri dan guru di lokasi pesantren. Pembagian tugas meliputi 3 orang untuk pemasangan dan perawatan panel, 4 orang untuk pengkabelan dan 3 orang lagi membantu di bagian pengadaan dan trouble shooting

Kegiatan pengabdian masyarakat diadakan pada tanggal 26 Oktober 2019 dengan agenda pemasangan panel surya di Pondok Pesantren Darul Bayan. Sebelum dilakukan pemasangan sistem terlebih dahulu dilakukan pengenalan mengenai sistem yang akan dipasang. Sistem yang akan di-install di pesantren dapat dilihat pada Gambar1. Penjelasan diawali dengan prinsip kerja dari panel surya, dan hal-hal apa saja yang dapat mempengaruhi kinerja dari panel surya serta bagaimana cara merawat agar panel surya tersebut tetap memberikan hasil yang maksimal. Kemudian diajarkan mengenai cara kerja konverter, mengapa dibutuhkan konverter, apa fungsinya dan apa yang harus dilakukan ketika konverter ini rusak. Materi yang ke tiga adalah instalasi jaringan, diajarkan mengenai macam-macam jaringan dan bagaimana implementasi on grid maupun off grid. Materi yang terakhir mengenai baterai yang digunakan, mengapa menggunakan baterai dan bagaimana memilih kapasitas baterai yang sesuai.

Panel surya yang dipasang sebanyak 3 buah dengan rating masing-masing $100 \mathrm{Wp}$ pada atap bangunan pesantren putri seperti ditunjukkan pada gambar 2 .

Setelah dilakukan pemasangan panel surya, dilakukan pengkabelan antar panel surya dan solar charger controller seperti ditunjukkan pada gambar 3. Kegiatan pengkabelan ini juga ditujukan untuk memberikan kesadaran kepada 
warga pesantren mengenai pentingnya pemasangan kabel yang sesuai kaidah yang benar untuk keselamatan penggunanya. Kegiatan dimulai dengan memberikan contoh kemudian diikuti oleh santri di bawah tim pengawasan PKM.

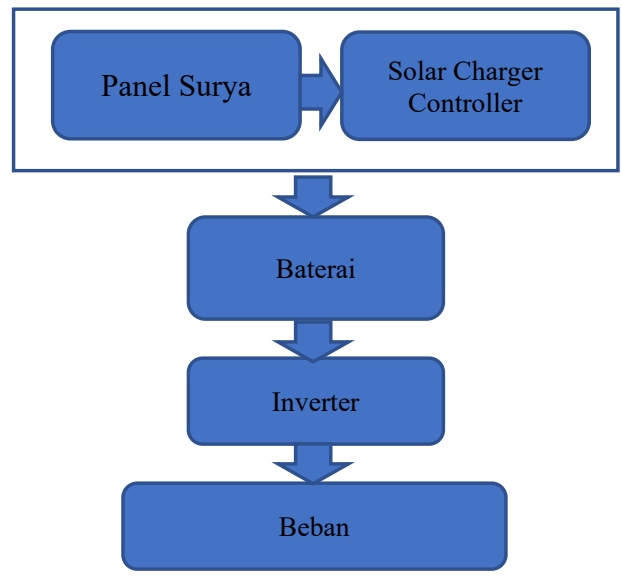

Gambar 1. Perancangan teknologi yang diterapkan

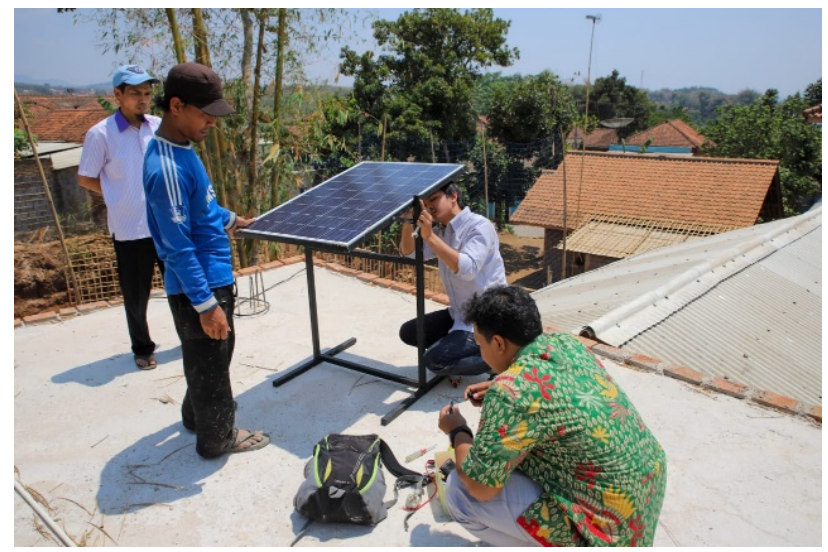

Gambar 2. Pemasangan panel surya

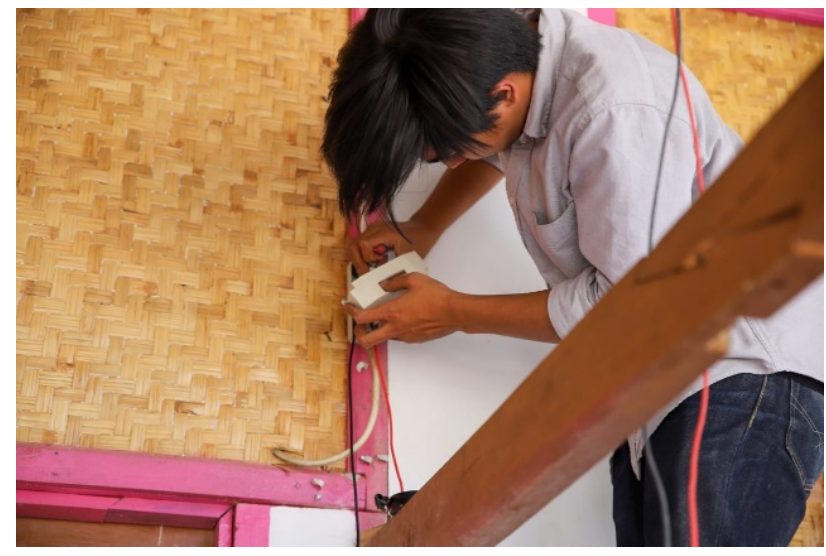

Gambar 3. Pengkabelan antar panel surya dan solar charger controller
Kemudian kegiatan dilanjutkan pada tanggal 28 Oktober dengan kegiatan perakitan/integrasi antara panel surya dan beban 4 lampu pada teras. Integrasi dilakukan untuk modul solar charger controller, baterai dan power inverter. Sebelum dilakukan perakitan perakitan terlebih dahulu diberikan penjelasan mengenai pembacaan datasheet komponen yang meliputi spesifikasi dan tipe beserta dengan cara kerja dan cara instalasinya. Hal ini dilakukan agar santri dapat melaporkan dengan benar kepada tim PKM jika ke depannya terdapat masalah pada sistem dan santri juga mengerti komponen yang perlu diganti/dibeli untuk memperbaiki sistem tersebut.

Proses perakitan/integrasi ditunjukkan pada gambar 4. Mulai dari instalasi konverter 4(a) dan diakhiri dengan proses pemasangan 4 buah lampu pada teras ditunjukkan pada gambar 4(b). Lampu yang digunakan adalah jenis lampu LED agar dapat menekan konsumsi pemakaian daya.

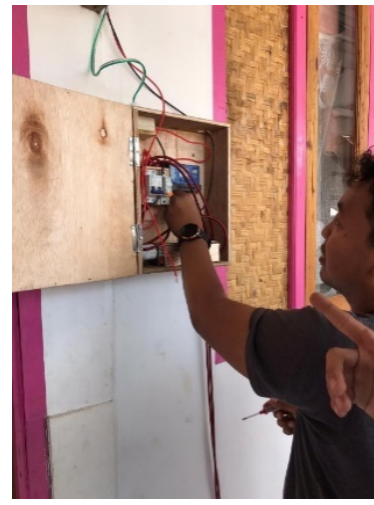

(a)

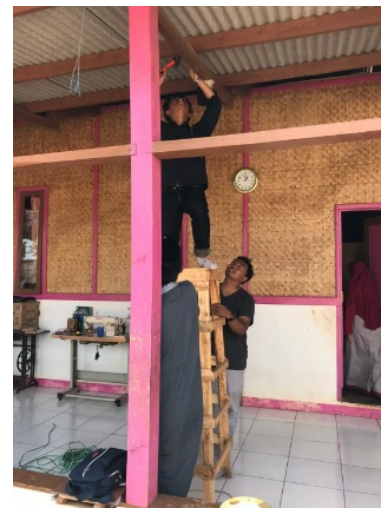

(b)
Keterangan:

(a) instalasi panel surya ke konverter asi (b)Instalasi lampu teras

Gambar 4. Proses instalasi

Hasil dari Sistem Pembangkit listrik Tenaga Surya adalah dapat menghidupkan lampu teras yang ditunjukkan pada gambar 5 .

Berdasarkan hasil pelaksanaan kegiatan, tim dapat memberikan beberapa analisa terkait perbandingan antara permasalahan masyarakat sasar terhadap keseluruhan hasil yang dicapai sebagai berikut: 
a. Sistem pembangkitan listrik menggunakan panel surya yang dipasang merupakan sistem off-grid

b. Pemasangan 3 buah panel surya $100 \mathrm{Wp}$ hanya dapat menghidupkan 4 buah lampu pada teras

c. Inverter yang dipasang merupakan inverter modified sine sehingga tidak dapat menyalakan beban pompa air.

d. Untuk dapat menghidupkan lampu dan pompa air (beban 900VA) dibutuhkan tambahan 3 buah panel surya $300 \mathrm{wp}$, baterai $12 \mathrm{~V}$ dengan kapasitas $300 \mathrm{Ah}$ dan inverter pure sine.

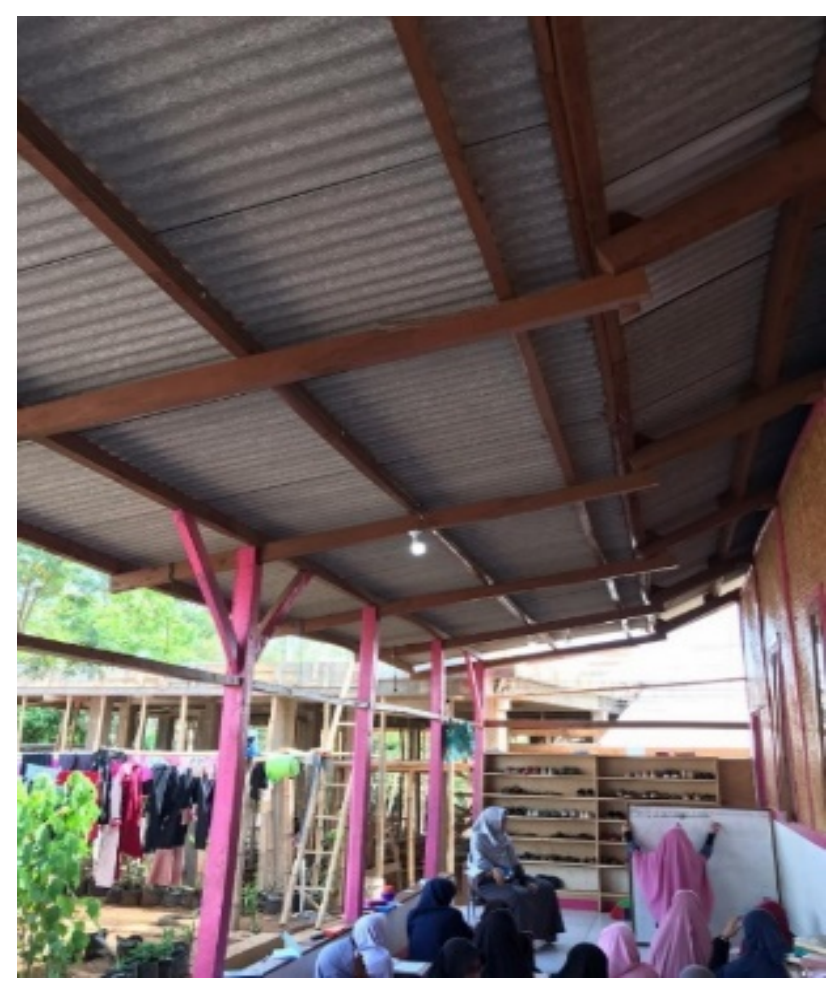

Gambar 5. Pengujian instalasi

Dari hasil pemasangan instalasi kelistrikan untuk lampu teras ini, maka pengeluaran yang dapat di hemat oleh pondok pesantren dengan asumsi nyala lampu selama 12 jam dari sore hingga pagi adalah $(18 \times 4) \times 30 x \quad 12=25920 \mathrm{Wh}$. Pondok menggunakan golongan 1300 VA ke atas, sehingga Tarif Dasar Listrik (TDL) yang dipakai adalah $\mathrm{Rp} 1.444,7 / \mathrm{kWh}$. Oleh karena itu estimasi penghematan setelah pemasangan panel surya ini adalah 25,92 x 1444,7= Rp 37.446/bulan atau diperkirakan $\mathrm{Rp} 449.359$ penghematan per tahun. Walaupun ini tidak terlalu signifikan jika dibandingkan dengan pengeluaran yang ditanggung, tetapi harapannya program ini dapat menjadi batu loncatan ke depannya agar pesantren ini mandiri baik secara ekonomi maupun energi.

Minimnya pengetahuan terkait ketenagalistrikan merupakan tantangan terbesar untuk tim PKM dalam melaksanakan penyuluhan. Hal ini dikarenakan peserta belum memiliki keterampilan dasar tentang kelistrikan, sehingga pengetahuan mengenai istilah-istilah kelistrikan masih sangat minim. Begitu juga dalam pembacaan datasheet dan spesifikasi komponen, sehingga membutuhkan waktu yang cukup lama dalam pelaksanaannya.

Di akhir kegiatan tim juga memberikan kuesioner sebagai bahan evaluasi untuk kegiatan yang akan datang. Pertanyaan yang diajukan meliputi apakah program sudah sesuai dengan tujuan, apakah program kegiatan sudah sesuai dengan kebutuhan masyarakat sasarnya, waktu pelaksanaan apakah telah sesuai, penyampaian materi apakah dibawakan dengan bagus, ramah dan mudah dimengerti dan pertanyaan terakhir mengenai harapan untuk diadakan kegiatan serupa pada periode berikutnya. Dari 10 peserta menjawab semua pertanyaan tersebut dengan sangat setuju. Sedangkan pada pertanyaan mengenai waktu pelaksanaan hanya ada 1 orang yang hanya menjawab setuju dan sisanya sangat setuju. Dari hasil kuesioner ini maka didapati bahwa masyarakat sasar sangat terbantu atas program ini dan berharap agar tetap berlanjut pada periode berikutnya.

\section{Kesimpulan}

Kegiatan integrasi modul energi surya di pondok pesantren Darul Bayan ini dapat disimpulkan bahwa kegiatan ini sangat bermanfaat bagi warga pesantren. Manfaat pelatihan ini dapat dilihat dari survei yang menunjukkan $100 \%$ peserta menilai kegiatan ini sangat berguna bagi warga pondok dan berharap akan dilanjutkan untuk dilakukan hal serupa pada waktu yang akan datang. Mitra sasar beranggapan bahwa kegiatan ini sudah sesuai dengan tujuan dan dibawakan oleh tim dengan baik dan memuaskan.

Saran untuk kegiatan yang akan dilakukan selanjutnya adalah penambahan panel surya agar listrik pesantren dapat mandiri tanpa harus terbebani oleh biaya bulanan dari listrik PLN. 


\section{Ucapan Terima Kasih}

Ucapan terima kasih sebesar-besarnya kepada Telkom University yang membiayai penuh kegiatan ini hingga berjalan dengan lancar dan banyak memberikan manfaat bagi masyarakat sasar. Selain itu, ucapan terima kasih juga diberikan kepada pihak pondok pesantren Darul Bayan yang turut membantu dalam menyukseskan kegiatan ini hingga akhir.

\section{Daftar Pustaka}

[1] Abrori, M., Sugiyanto, S., Niyartama, T.F., 2017. Pemanfaatan Solar Cell Sebagai Sumber Energi Alternatif dan Media Pembelajaran Praktikum Siswa Di Pondok Pesantren "Nurul Iman" Sorogenen Timbulharjo, Sewon, Bantul, Yogyakarta Menuju Pondok Mandiri Energi. J. Bakti Saintek J. Pengabdi. Masy. Bid. Sains dan Teknol. 1, 17. https://doi.org/10.14421/jbs.1131

[2] Hafidh, Z., Badrudin, B., 2019. Pesantren dan Kemandirian Perekonomian: Studi tentang Kewirausahaan di Pondok Pesantren Ar-Risalah Cijantung IV Ciamis. Manag. J. Manaj. Pendidik. Islam 3, 257-267. https://doi.org/10.14421/manageria.2018.32-03

[3] Nurmahaludin, N., Cahyono, G.R., 2020. Instalasi Listrik Tenaga Surya Untuk Penerangan Di Pondok Pesantren Mahad Arrahman. J. IMPACT Implement. Action 2. https://doi.org/10.31961/impact.v2i1.797

[4] Solichin, M.M., 2012. Kemandirian Pesantren di Era Reformasi. Nuansa 9, 191-192. 